\title{
COMPARISON OF MODULAR AND TRADITIONAL UK HOUSING CONSTRUCTION: A BIBLIOMETRIC ANALYSIS
}

\begin{abstract}
Purpose - Housing completions in the UK have fallen to 125,000 annually, while government targets have risen to 300,000 . This dramatic shortfall raises concerns as to whether current traditional construction approaches remain appropriate. This study, aims to compare the traditional approach with modular construction, with a view to assessing whether a shift in construction systems offers the potential to alleviate UKs domestic housing crisis.

Methodological Approach - A comprehensive interpretivist review of the available relevant literature is undertaken on construction methods within the UK; advantages and disadvantages. A bibliometric analysis is conducted to extract trends and findings relevant to the comparison at hand. The database is Web of Science; the analysis software is VOS Viewer.

Findings: The research illustrates that UK housing market is in a state of crisis. A toxic combination of a rising UK population combined falling rates of housing delivery has resulted in an ever-widening housing supply gap. The construction industry's capacity to meet this observed dearth in supply is further exacerbated by a number of chronic factors such as: falling participation in the construction sector workforce; lowering skills levels; reducing profitability; time to delivery pressures; and cost blow-outs.
\end{abstract}

Originality - While much information on the various construction methods are available, including comparative material, this work is the first to assemble the various comparative parameters regarding traditional and modular UK residential construction in one place. Thus, this study provides a definitive assessment of the relative advantages and disadvantages of these forms of construction.

KEYWORDS - Modular Construction, Traditional Construction, Modular Housing, Residential Housing, Construction Costs, UK housing

\section{1 - INTRODUCTION}

The construction industry contributed $£ 113$ billion to the UK's economy, in 2017, with construction output in the $3^{\text {rd }}$ Quarter of 2018 approximately $14 \%$ higher than for the quarterly output of the previous year (Experian, 2018). Of this, housing orders in the UK were worth $£ 41$ billion (Rhodes, 2018). Within the housing construction sector, there is a high concentration of 
micro businesses (1 to 9 employees) and small businesses (10 to 49 employees) (GOV.UK, 2019). Indeed, $99 \%$ of all contractors are micro or micro businesses, while $65 \%$ of construction product businesses are similarly sized. Only $1.2 \%$ of construction firms have 250 or more employees (GOV.UK, 2019). Currently, around 33,000 architectural services firms are micro businesses, with only 125 firms employing over 250 people (Open Government Licence, 2018). The industry is large and growing, but the players are small-scale operatives.

Within this context, the UK is experiencing a massive housing shortage, requiring some 300,000 houses per year to match demand (Mulheirn, 2019). Indeed, this demand is not being met. Housing completions have fallen to historically low levels of around 125,000 per year (Legal and General Group, 2014). Given this abject failure to deliver on target, the question arises as to whether a shift from current, traditional building methods to more progressive approaches could alleviate this market collapse, and provide the needed housing quicker and even cheaper (Leppänen, 2019). One significant factor perpetuating the slow process of house builds and current shortfall is seen to be the construction industries chronic reliance on a limited number of big players, and the exclusion of the myriad micro and small firms, and alternative construction modes such as modular construction (Ministry of Housing, Communities and Local Government, 2017).

This paper investigates this problem, specifically comparing traditional and modular building methods extant to the UK's housing sector, with a view to assessing the potential for modular housing methods to alleviate the housing stock shortfall experienced under the current traditional construction regime. Concomitant objectives are to: i) evaluate the current traditional brick-built method used in the UK; ii) assess time, cost and quality factors pertinent to residential buildings in the UK; iii) evaluate the sustainability of modular construction in comparison to traditional methods; and iv) forecast the future of the UK's construction industry and the role of modular methods in resolving the UK housing crisis.

\section{2 - RESEARCH APPROACH}

The overarching epistemological design for this research adopted an interpretivist stance (Saunders et al., 2009; Roberts et al., 2019; Al-Saeed et al., 2020) using extant literature as a secondary data source and unit of analysis (Greenhoot and Dowsett, 2012; Chamberlain et al., 2019). From an operational perspective, the research employed a two-stage process to conduct a bibliometric literature review (cf. Dixon et al., 2020). First, a manual search of the literature 
was conducted to determine keywords. These keywords were: UK housing, housing crisis, construction costs, traditional construction, modular construction, masonry, and sustainability. Keywords were then used to search the Scopus and Web of Science abstract and citation database to retrieve articles and documents relevant to the study at hand. Secondly, VOS Viewer software was used to showcase and present data extracted from the literature search in order to facilitate a bibliometric analysis.

\section{1 - Scientometric analysis}

The approach taken is one of scientometric analysis. In this approach, computer aided tools are used to quantify and analyze the selected database (Yalcinkaya and Singh, 2015). The scholarly data on traditional and modular construction in the UK is mapped and visually represented, as codified by Van Eck and Waltman (2010), then analyzed and interpreted as described by (Cobo et al., 2011). A variety of scientometric analysis tools are available, with features and limitations common to all. These include VOS Viewer, BibExcel, CiteSpace, CoPalRed, Sci2, VantagePoint and Gephi (ibid). Of these, VOS Viewer (www.vosviewer.com) was selected. VOS is an acronym for 'visualization of similarities.' VOS Viewer is easy to use, freely available, with results intuitively comprehensible. Moreover, of the tools available for bibliometric analysis, it presents as one most commonly adopted by construction researchers (Jin et al., 2018).

\section{3 - ANALYSIS AND FINDINGS}

The retrieved documents speak to a number of factors relevant to the UK housing crisis. It is of interest to note the range of issues that emerge, as much as what can be inferred with respect to those issues. This section presents the bibliometric findings with regard to: i) meta-analysis: authors, research themes, and documents; ii) state of the UK construction sector: current performance and future ambitions; iii) UK housing shortfalls, iv) declining housing availability, v) traditional vs. modular housing construction methods, and vi) cost comparisons.

\section{1 - Bibliometric meta-analysis}

A broad analysis of the state of research with respect to UK housing was conducted, mapping key dimensions such author participation, thematic content, and chronological publications trend.

\subsection{1 - Research authors}


A VOS Viewer network was produced to identify authors publishing in the field of UK housing builds. The data for the author field was extracted from Scopus and Web of Science databases which returned 1,279 research articles and academic papers published between the time period of 1991-2018. Of these publications, 78 authors show research linkages with others. Figure 1 shows nodes of varying size, being proportionate to the number of occurrences and cooccurrences of citations used by the authors. The most prominent author with the largest visible weighting is Michael Davies, a renowned academic from University College London. His research focuses on construction building technology as well as on aspects of environmental sciences. Paul Wilkinson is another influential academic scholar identified whose work also focuses on construction building technology, but also on meteorological atmospheric sciences. Both authors have numerous interconnectivities with scholars in the middle and periphery of the overall cluster map. Overall, however, research into UK housing is a limited research field, with few dedicated experts commenting extensively on the matter, and with numerous others delving in limited degrees on various housing issues.

\section{$<<$ Insert Figure 1 here $>>$}

\subsection{2 - UK housing research themes}

An inspection of the VOS Viewer network generated on topics found within the broader research theme of UK housing, shows wide-ranging terminology. See Figure 2. Titles and abstracts were used to locate terminology relevant to the study. A total of 8,025 terms had cooccurrences across published academic papers. However, these were filtered to only display terms that had a co-occurrence factor of five or more (at least five different academic papers). As a result, the output reduced to 290 terms. Housing, performance, population were some of the popular terms returned. A closer examination, however, reveals a bivariate distribution. The dominant research pursuits are within the related domains of energy, performance and sustainability. The secondary cluster grouping is vaguer, but it can be inferred from the terms with the group that research here is preoccupied with social issues. Of especial note is the general absence of housing shortage and construction modes as a remedy to that shortage. Thus, while rising demand and falling supply has left the UK in chronic need of housing, the literature, remains preoccupied with mostly sustainability related issues.

\section{$<<$ Insert Figure 2 here $>>$}




\subsection{3 - Frequency of document publication}

Perhaps the neglect in research on UKs housing construction methods becomes clearer when the number of publications, year on year, are considered. These are shown in Table 1. Interest in the theme only begins to gain traction this century. And despite some small surges in output in certain years (2006, 2010, 2013 - 5 publications; 2012 - 7), it has only been over the last half decade that publication levels have been sustained. Even so, as already noted, given the importance of the crisis, the publication record does not seem to adequately reflect the importance of the problem; there were only three publications on UK housing methods in 2019.

\section{$<$ Insert Table 1 here $>>$}

\section{2 - State of the UK construction sector}

Turning from the broader consideration of research publication meta-metrics - the authors, the research themes, and the number of publications - it is necessary to consider that actual state of UK housing. This includes current performance and future expectations.

\subsection{1 - Comparative performance of the UK construction sector}

The UK construction industry is of major importance to the UK economy, accounting for $6 \%$ of GDP and providing jobs for 7\% of the workforce (Romei, 2019). Moreover, global as well as domestic opportunities in construction mean a skilled workforce remains vital to the UK's construction sector in terms of the performance and competitiveness (Barawas et al., 2013). More pointedly, the UKs housing industry is growing, while that of most of the rest of Europe is declining. See Table 2. The ONS index for Europe as a whole fell from 116, in 2009, to 107, in 2018. Over the same period, the UK index rose from 85 to 110. This was higher than Germany's rise from 93 to 109, the EUs largest economy and contrast considerably with the falls experienced by Spain (137 to 106), France (115 to 102) and Italy (152 to 107). A final observation, however, is that this UK growth has stalled over the last year - 2018-19.

\section{$<$ Insert Table 2 here $>>$}

\subsection{2 - UK government strategic construction sector ambitions}

The UK housing market conditions, and status with respect to Europe, needs also to be set against the UK governments overall strategy plan and aspirations. In this regard, the governments Construction 2025 report is instructive. It sets out targets to ensure the 
construction industry 'thrives' in the continued face of increasing global competition (Glenigan, 2019). See Table 3. The main factors considered are costs, including both initial and whole life, construction time, emissions reduction, and closure of the trade gap in terms of both materials and products. Additionally, emphasis is placed on utilizing modern construction methods as one of the main pillars in facilitating UK construction services ability to deliver buildings faster and cheaper (Pitts, 2019).

\section{$<<$ Insert Table 3 here $>>$}

\section{3 - UK housing shortfall crisis}

The UK government has set a target of 300,000 new house builds annually. In fact, builds over the last forty years continue to decline. And even as investment in private housing is on the rise, that of public housing continues to fall dramatically.

\subsection{1 - Pressures on the UK housing market}

UK, house prices are on the rise, becoming ever increasingly unaffordable. This is attributable to new builds consistently failing to meet projected rates of household formation (Hudson, 2018). According to the most recent statistics published by MHCLG, 165,090 new-build homes were completed in the year to December 2018. This is despite a figure of net additional dwellings required of 222,190 - representing a shortfall of 57,100. (Dunton, 2019). While the government had set a target of 300,000 new home builds per year, to 2020, only an average of 160,000 houses have been built yearly since the 1970s - again representing a shortfall; this time of 140,000 per year (Davies, 2018). Simply, the UK is facing high customer demand, under conditions of growing population. In 2016 alone, the population increased by 538,500 (Civitas, 2017) and is projected to increase a further 9.7 million by 2039 .

This remarkable deficiency is blamed primarily on an aging workforce and a failure to replace retiring workers, combined with reducing skills levels, and a consequent decline in overall productivity. $22 \%$ of the current construction workers are over 50 and $15 \%$ are in their $60 \mathrm{~s}$ (Construction Magazine UK, 2019). The recruitment of fresh, young workers is needed, but absent or ineffectual. Moreover, the turnaround time of housing construction is a further detracting factor, with greater pressure put on delivering houses ever faster, typically compromising quality, especially under the added constraints of rebuilding in higher density locales (Cheshire and Hilber, 2019). 
Additionally, increasing consciousness regarding waste production and efforts to augment sustainable practices add to the pressures. In the UK, construction industry uses approximately 400 million tonnes of materials annually, producing 100 million tonnes of waste, with 25 million tonnes disposed to landfills (Wrap, 2019). These pressures have echoes of past challenges which could be expected to encourage use of off-site methods such as modular construction (NHBC Foundation, 2016).

\subsection{2 - Declining housing procurement, despite rising demand}

Figure 3 shows a bivariate regression model of house builds, in the UK, over the period 1978 to 2018. Only in that first year were house builds close to the annual government target, set at 300,000. The overall decline has been consistent and steady, with the uptick of 2018 nevertheless remarkably below par, at less than 200,000. There have been some cyclical trends. 2007 to 2010 saw a downswing from 223,590 to 135,980 builds. Presently, it looks like the cycle is riding an upswing - though, even if sustained, the 2018 figure of 198,050 can hardly be expected to reach the lofty government target.

\section{$<<$ Insert Figure 3 here $>>$}

Table 4 shows orders in 2018 had fallen below 2011 figures for public housing and public works. The maximum new orders value on record occurred in 2017 , at $£ 70,987$ million due to the awarding of several high-value contracts relating to High Speed 2 (HS2). This is evident from the large value of infrastructure relative to the other series, contributing to a record quarter-on-quarter growth of 54\% in Quarter 3 (July to Sept) 2017. As such, infrastructure coming back down from this value was the largest contributor to the $£ 9,335$ million $(13.2 \%)$ overall fall in value of construction new orders in 2018 compared with 2017 (ONS, 2019).

\section{$<<$ Insert Table 4 here $>>$}

\section{4 - Declining housing availability}

Social housing a public service where housing is let at below market level rents, or sold through shared ownership. This type of housing is made available to help those whose needs are not served by the market (KPMG, 2019). While around $45 \%$ of all under 40 s can afford to purchase homes, this percentage reduces to $34 \%$ in the private rental sector. Currently, councils across 
the UK are struggling to provide homeless people with a place to live - meaning thousands of individuals are reduced to living in hostel accommodation, or end up homeless and on the streets. Moreover, a high number of people living hand to mouth, are in perennial danger of losing their homes as housing costs rise (Bramley, 2018).

Approximately 126,000 social houses were built yearly by Conservative and Labour governments during the period from the Second World War to 1980. The subsequent decline in social housing is attributable to a range of factors, but predominantly due to a failure to build enough homes to meet demand. Over the past five years, housebuilding has averaged 166,000 a year, yet the UK government intends to produce 300,000 homes a year. The under-provision of social housing has reduced it into service available only to those people in the very most need. Still, at present, around 277,000 people remain homeless in the UK as a consequence of welfare provision collapse in the face rising costs, increasing demand and limited governmental budgets (Shelter, 2019). Table 5 illustrates the affordability bands of all under-40 households in England, by regions. As can be seen, Greater London, where the jobs are, is the least affordable. This generates a further paradox. Unemployed people seeking to re-enter the workforce may find even greater pressure in locating affordable housing; while those retreating to more affordable regions of the UK may not be able to regain employment.

\section{$<$ Insert Table 5 here $>>$}

\section{5 - Traditional housing construction}

Traditional construction involves a process where all primary structural elements are constructed entirely on site; usually referred as stick-built or conventional construction. Traditional construction describes a process of linear construction, where sequential steps are executed on site in a progressive fashion - one activity must be completed before the next can take place (Reds10, 2015). Normally, in the UK the building process involves foundations being laid, walls and roofs added, and with interior elements finalized before the dwelling is handed over to the end user (Building Specifier, 2018).

\subsection{1 - Masonry construction in the UK}

The traditional masonry method is still currently the most popular method of housing developments in the UK. This type of process refers to houses built in brick or blockwork where these elements are used to form an outer skin for buildings. The process comprises bricklayers erecting cavity walls, consisting of an inner and outer skin. The inner skin is the 
key structural element that supports the internal floors and roof structure and is formed with the use of concrete blocks laid on beds of cement mortar. On the other hand, the outer skin offers protection against the elements and provides an aesthetic element to the building with the formation of brick, stone or blockwork. Both skins are linked by steel wall ties and are separated by a cavity which is partially filled with insulation (The Self Build Guide, 2019). Masonry construction is by far the popular building method used in the UK. See Figure 5.

\section{$<<$ Insert Figure 5 here $>>$}

Traditional masonry construction continues to dominate UK's residential dwelling construction, as it has done for generations (NHBC Foundation, 2016). The highest recent percentage of market share for masonry was in 2012, at $72 \%$. This slipped by $2 \%$ into 2015 . This was due to an uptick in alternative methods. Masonry is designed and built to last approximately 150 years, while being manufactured from responsibly sourced local materials in the UK. Installation is carried out on-site by skilled tradesmen allowing (Ancon, 2019). The popularity of this building method continues to endure, with only peripheral enhancements to the method being introduced. The advantages and disadvantages of masonry construction are summarized in Table 6. While masonry remains popular, it does suffer from slowness in construction, higher costs and exposure to rising damp.

\section{$<<$ Insert Table 6 here $>>$}

\subsection{2 - Limitations of traditional masonry construction}

It takes about 20 weeks to complete traditional masonry house, and this extended time frame is contributing to the UKs housing shortage problem (Brooks, 2012). Brick homes are built by hand, one brick at a time. Thus, more laborers are required on site, working long hours, at relatively high cost (Root III, 2019). Moreover, masonry construction involves the delivery of very heavy materials which cannot be transported by conventional vehicles, and this adds to the costs and time involved (Edenhall, 2017). Masonry construction cannot be carried out during heavy rain or freezing conditions, since mortar will be severely affected, among other difficulties, and this again curtails timely project delivery (Muresan, 2019).

\section{6 - Modular housing construction methods}


Modern methods of construction (MMC) have existed since the early $20^{\text {th }}$ century, after gaining popularity especially in the housing sector between 1910-1940 (Modular Today, 2019). Furthermore, the demand for housing in the UK met housing/business needs as well as schooling and other sectors. Challenges within the construction industry means it is becoming difficult to meet these growing requirements while still maintaining high standards (Elliott, 2019). According to both Latham and Egan reports, the emphasis on standardisation and preassembly techniques in the UK's construction sector was discussed and stressed the importance of modular systems to improve overall construction performance (Nawi et al, 2014). Modular construction defines substantial elements of a building that are factoryproduced and delivered on site for assembly, where the most common form of method includes volumetric systems as prefabrication is used to produce complete 3D structural units (generally steel frame/precast concrete/timber etc.). The main process involves modules being fully fitted out in the factory where the units are driven to site and craned into position with combinations if necessary (Edwards et al., 2003; Construction Methods Modular, 2018). Alternative modular forms include panel systems where 2D panels are prefabricated and are delivered to site to be craned into positions and use of pods which are small prefabricated units usually fully fitted out and use in conjunction with other construction methods (ibid). The process is highly automated (Edwards et al., 2017) and moves towards an Industry 4.0 solution (cf. Newman et al., 2020). By removing manual trades from the fabrication processes, this method of housing building could reduce accidents on site (Riaz et al., 2006); lower maintenance costs of mobile off-highway plant and machinery (Edwards et al., 1998) and augment safe productivity enhancement (cf. Edwards et al., 2019; Edwards et al., 2020). Modern construction has been recognised for its ability to help solve the housing shortage problem in the UK from the design stage go the production of high quality pre-built homes at a faster rate (Davies, 2018). Modern MMC therefore offers a solution - providing flexible, affordable and superior finishes for a wide range of uses (Elliott, 2019).

\subsection{1 - The benefits of modular construction}

The greater use of modular construction in the UK would provide a significant contribution to much needed housing completions across all tenures, delivering additional approaches to build the homes needed yearly, complementing to more traditional methods, thereby growing the number of participants and development options (Hooper, 2019). The involvement of readymade housing sections which are assembled on site thereby reducing on-site labour costs. As the process is based in a factory-controlled environment, alongside the use of easy-to-transport 
modular components, this therefore reduces the cost of production. Moreover, the final completion is handled by the general contractor who ensures utilities are connected and all modular units are attached for finishing works (Zhao and Riffat, 2019). According to Tom Ground (CEO of Legal \& General Homes), offsite manufacturing residential housing is crucial to address the housing crisis, due to the provision of quicker building processes whilst achieving greater cost certainties (KPMG, 2019).

Internationally, countries such as Canada are already implementing the use of modular construction for residential buildings, particularly in their capital city Vancouver to tackle homelessness rates, including in 2017 where 3,605 people were homeless in Metro Vancouver. The government invested \$291 million over two years to build over 1300 modular homes for people on low incomes. Furthermore, the government decided to allocate $\$ 216$ million through 2020 for staffing and support services (Williams, 2018). Every module is delivered to site in the highest quality where it is fully finished, with roofs and windows, meaning overall a speedier process with quality maintained (NHBC, 2018).

\section{$<$ Insert Table 7 here $>>$}

Table 7 presents the advantages and disadvantages of modular construction for housing within the UK. One of the main benefits is the quicker process, which is key to solving the housing crisis in the UK. In addition, the cost effectiveness provided will allow the construction of houses to be built at a cheaper rate compared with the traditional route. On the other hand, a drawback is the lack of experience and skills that the sector may be in need of with regards to modular builds. If this were redressed, with specific emphasis on the benefits of modular housing, this would stimulate the economy with more factory builds and more jobs.

Modular construction has the potential for alleviating the housing crisis in the UK. With an inclusive faster process compared to the traditional bricks and mortar method. Moreover, the controlled factory environment of modular construction ensures consistent quality, and completions at a faster pace (Arup, 2019). Modular construction is moreover well-suited to the traditional market, self-built homes, social housing and built-to-rent uses. Both public and private sector developers have shown interest in build-to-rent schemes, where the financing of modular methods is especially attractive (London Assembly, 2017). 


\subsection{2 - The sustainability of modular construction}

Sustainable Construction uses the principles of sustainable development to the built environment sector by involving the delivery of all buildings/structures/infrastructure that maximise the efficient use of resources, in order to reduce pollution and waste as well as energy consumption (Stubbs, 2008). The UK government's Code for Sustainable Homes (CfSH) is the main environmental standard used in the domestic sector. Many developers encourage ecofriendly credentials, using sustainable materials and construction methods for the build, and incorporating eco features such as solar panels, ground source heating, and rainwater collection systems with the modular process (Curtis, 2018). This makes homes more environmentally friendly leading to cheaper running costs for the end user. Potentially, modular buildings can also be dismantled and re-used, thereby effectively maintaining their asset value and off-site production generally leads to approximately $15 \%$ of materials and wastage savings (Oliveira et al, 2019). The primary use of energy over the building's life lies with its operational energy of heating and even cooling. Modular homes can be designed to be highly insulated and very air-tight, alongside being lightweight, where the modular arrangement of a house can weigh less than $30 \%$ of a typical concrete frame (Frigione et al, 2019). According to the Building Research Establishment, an average of $13 \%$ material wastage on site is stated in the UK construction industry (John and Itodo, 2013). Subsequently, this is reduced greatly in modular construction with all off-cuts entirely recycled in the factory. Site management is enhanced by the just-in-time delivery method of the modules alongside the minimal requirement of materials storage on site (MTC, 2019). Due to efficient traffic management, site deliveries traffic is decreased by up to 70\%, with minimal noise and other sources of disturbance (Lawson, 2014). Furthermore, modular construction can reduce up to $90 \%$ of waste generated compared to the traditional method with the use of recyclable material being a key factor (Actavo, 2019). Modular housing construction can also require up to 67\% less energy (Wrap, 2007) allowing each house to be energy-efficient throughout its lifecycle as the installations of energy-efficient systems (such as solar panels) make a huge difference.

\section{7 - Cost comparisons}

Whilst cost is a big factor in developing affordable social housing in a quick, efficient manner, the actual construction costs differ tremendously between traditional and modular housing schemes. Table 8 presents a breakdown of the two cost models: the first illustrating a modular housing development comprising of 160 residential apartments, contrasting to a traditional cost model of an affordable housing scheme of 162 open market units and 54 flats. The modular 
cost model comprises 160,500 feet squared of gross internal floor area for a private tenure project based in London Zone 3, whilst the traditional housing cost model had a gross internal floor area of 80,407 feet squared and is also based in London Zone 2/3 of the affordable sector. The modular cost model was provided by a worldwide multinational engineering firm who have now implemented the use of modular construction. On the other hand, the affordable housing cost model has been given by a different company, showcasing the traditional building method to help aid tenants with low incomes. They were however some limitations to the models; one factor is that the homes are not directly comparable, and another reason is that these are case studies so different results are produced. Additionally, a larger sample could have been used to present the cost differences in building affordable modular development compared to the standard traditional.

\section{$<$ Insert Table 8 here $>>$}

Table 8 data compares builds for a comparable residential development with the same number of units at the same location. The price per metre squared for modular units is $£ 2,307$, compared to $£ 2,977$ for the traditional construction model. The figures indicate that utilising modular construction for the development of residential apartments is cheaper by $£ 670$, per metre. What we do see from the cost comparison table, however, is that while overall costs are cheaper for modular, it is not necessarily cheaper at every item. Indeed, some aspects of modular construction are higher in cost. This includes fittings, furnishings and equipment, water installations, space heating, ventilation, electrical, and communications, amongst others. However, these items are mostly service related. Fundamental construction elements are invariably cheaper with modular construction when compared to traditional. Specifically, to name a few, substructure, frames, roof, walls, floor, and the like, are all cheaper when constructed using modular techniques.

For the modular method, productivity benefits are significant, and labour costs in production are reduced by at approximately $30 \%$ relative to on-site work, with site personnel reducing by over 70\% (Lawson and Ogden, 2014). Onsite assembly of modules also requires a lowerskilled and hence lower-cost labour force. Approximately 25 percent of time onsite is spent creating value while 75 percent of time spent offsite creates value (Bertram et al, 2019). Overall, we expect the transitioning to modular to reduce the labour costs significantly. Site preliminary costs are taken as $5 \%$ for fully modular houses, leading to a saving of $7-10 \%$ in 
comparison to traditional. (Lawson and Ogden, 2014). As a result, the cost models show that for this project, modular construction is $£ 11,137,509$ less compared to that of a traditional method. Overall, modular construction is cheaper and faster, with quality at least comparable.

\section{4 - DISCUSSION}

According to the Housing Forum (2019), Modern Methods of Construction (MMC) is stated to be not a new concept. It was strongly encouraged by Sir John Egan [Rethinking Construction 1998] that the construction industry in the UK is under-achieving and in need for dramatic improvements. Paul Hackett, CEO of the Bartlett School of Construction and Project Management indicated that in 2018 housing associations spent $£ 10.7$ billion on new build (UCL, 2019).

The construction industry is atomised, with an over-dependence on trade skills, undercapitalisation and involved a steady decline in manual and skilled trades (Green, 2016). Paul critically mentioned this level of investment in affordable housing there must be more that could be done to improve efficiency, quality and value for money (Housing Forum, 2019). The need for greater productivity in construction, advancing in digital technologies such as building information modelling (BIM) and greater onus on building safety are some of the key drivers of adoption for the modular construction method. The use of digital design in MMC allows asset management teams to be presented with a BIM asset information model which will contain all the relevant data about the materials and components used (Historic England, 2019).

As these types of outputs become more common, asset management teams and their systems will need to adapt to receive them. A team engaged with an MMC project may be a useful catalyst (Housing Forum, 2019). One of the key indicators to why affordable housing developers adopting MMC was time-consuming is not to do with quality/longevity, but the challenges of procuring products and suppliers (LABC, 2019), due to the unwillingness to alter the design and build contracts (which most homes are procured through) with no compatibility of MMC. Alternatively, NEC contracts provide a number of processes used to support the successful integration of offsite manufacturing into the creation/maintenance of assets (NEC4, 2018). Distresses regarding the accessibility of mortgages for MMC and the willingness of landlords' lenders to accept the properties is contemplated.

\section{5 - CONCLUSION}


UK housing is in a state of crisis. Rising UK population combined falling rates of housing delivery has resulted in an ever-widening housing supply gap. The capacity of the construction industry to meet this increasing housing demand is further incapacitated by a number of chronic factors; falling participation in the construction sector workforce, lowering skills levels, reducing profitability, time to delivery pressures and cost blow-outs. The UK government has specified a housing supply target of 300,000 units annually. However, since the late 1970's rates of house builds have been steadily on the decline. Indeed, over the period 2010 to 2015, units delivered were below 150,000 per year. Since then, there has been an upswing, but the 2018 figure remains below 200,000 - far below the government's stipulation of 300,000.

This study has sought to explore this problem. It begins with a bibliometric survey of the literature in the area, noting that little has been researched on remediating this problem, with the focus more on 'sustainability' related issues - not the crisis at hand. It goes on to discuss methods of construction, identifying traditional masonry construction, while popular, as inefficient when compared to emerging modular forms of construction. This study focuses on this comparison, concluding that modular construction effectively outperforms traditional construction, especially in regards to cost, time and quality - all factors currently weighing down supply side delivery of UK housing. Cost of modular construction is shown to be $22 \%$ less than for traditional construction.

In short, modular construction promises strategic solutions to the lack of affordable housing currently experienced in the UK. This study is, however, limited in being primarily dependent on secondary data. It is therefore recommended that further empirical research be conducted to determine with greater certainty how modular methods can be more effectively grafted onto the current UK construction practices.

\section{ACKNOWLEDGEMENTS}

First of all, the first author wishes to praise the almighty Allah SWT - for giving the blessing and strength to complete this research study. The first author also wishes to express their sincere thanks and gratitude to all of the professional practitioners and organisations that have participated in this research, as well as family members of his beloved parents and brothers. Without your support and encouragement, this paper could not have been published. 


\section{REFERENCES}

Actavo. (2019) 4 reasons why modular is more sustainable than traditional construction. [online] Available at: https://actavo.com/latest-news/4-reasons-why-modular-is-moresustainable-than-traditional-construction/ [Accessed 9 April 2020].

AECOM. (2017) Cost model - Modular construction. [pdf] pp. 10-17. Available at: https://www.aecom.com/without-limits/wpcontent/uploads/2017/05/LM00092_Modular_CM_0417_v3.pdf_Accessed 1 Nov. 2019].

Al-Saeed, Y., Edwards, D. and Scaysbrook, S. (2020) Automating construction manufacturing procedures using BIM digital objects (BDOs): Case study of knowledge transfer partnership project in UK, Construction Innovation, Vol. ahead-of-print No. ahead-ofprint. DOI: https://doi.org/10.1108/CI-12-2019-0141

Ancon. (2019) Wall Ties \& Restraint Fixings. [online]. Available at: https://www.ancon.co.uk/products/wall-ties-restraint-fixings/technicalinformation/why-build-with-masonry [Accessed 29 Nov. 2019].

Arup. (2019) Solving the housing crisis: How Modern Methods of Construction can deliver 'more' through the planning system. pp.4-5. Available at: http://thinkhouse.org.uk/2019/arup.pdf [Accessed 22 Nov. 2019].

Barawas, M., Fleetwood, C., Folwell, K., Garnett, R., Hacche, I. and Liley, J. (2013) UK CONSTRUCTION - An economic analysis of the sector. Department of Business Innovation and Skills, London. pp.5-6. Available at:

https://assets.publishing.service.gov.uk/government/uploads/system/uploads/attachme nt_data/file/210060/bis-13-958-uk-construction-an-economic-analysis-of-sector.pdf [Accessed 25 Nov. 2019].

Bertram, N., Fuchs, S., Mischke, J., Palter, R., Strube, G. and Woetzel, J. (2019) Modular construction: From projects to products. [pdf] pp. 14. Available at: https://www.mckinsey.com/ /media/mckinsey/industries/capital\%20projects\%20and\% 20infrastructure/our\%20insights/modular\%20construction\%20from\%20projects\%20to \%20products \%20new/modular-construction-from-projects-to-products-full-reportnew.ashx [Accessed 12 Dec. 2019].

Bird, D.K. (2009) The use of questionnaires for acquiring information on public perception of natural hazards and risk mitigation -a review of current knowledge and practice, Natural Hazards and Earth System Sciences, Vol. 9, No. 4. DOI: https://doi.org/10.5194/nhess9-1307-2009 
Bramley, G. (2018) Housing supply requirements across Great Britain: for low-income households and homeless people. [pdf] pp.6,10-11. Available at: https://www.crisis.org.uk/media/239700/crisis_housing_supply_requirements_across_g reat_britain_2018.pdf [Accessed 19 Nov. 2019].

Brick Hunter. (2019) Brick or Render? [online] Available at: https://brickhunter.com/blog/brick-or-render [Accessed 11 Nov. 2019].

Brigden, M. (2013) The Pros and Cons of Brick and Block Construction - The Green Home. [online] The Green Home. Available at: http://thegreenhome.co.uk/builingproducts/brick-and-block-construction/ [Accessed 5 Nov. 2019].

Brooks, E. (2012) Building with Brick and Block - Build It. [online] Build It. Available at: https://www.self-build.co.uk/building-brick-and-block/ [Accessed 14 Nov. 2019].

Building Specifier. (2018) Modular Vs. Traditional Construction - Building Specifier. [online] Available at: https://buildingspecifier.com/modular-vs-traditional-construction/ [Accessed 11 Nov. 2019].

Chamberlain, D., Edwards, D.J., Lai, J. and Thwala, W.D. (2019) Mega event management of formula one grand prix: an analysis of literature. Facilities. Vol. 37, No. 13/14, pp. 11661184. DOI: https://doi.org/10.1108/F-07-2018-0085

Cheshire, P. and Hilber, C. (2019) The UK's housing crisis: what should the next government do? [online]. Available at: https://blogs.lse.ac.uk/politicsandpolicy/housing-crisis-whatshould-the-next-government-do/ [Accessed 4 Dec. 2019].

Chevin, D. (2018) Latest BOPAS news \& events. [online] Buildoffsite Property Assurance Scheme (BOPAS). Available at: https://www.bopas.org/news-and-events/are-factorymade-homes-really-on-the-road-to-becoming-mainstream/ [Accessed 12 Nov. 2019].

Chevin, D. and Clarke, L. (2019) MMC for affordable housing developers. [pdf] The Housing Forum. Available at: https://www.buildoffsite.com/content/uploads/2019/09/mmcguide-2019.pdf [Accessed 17 Nov. 2019].

Civitas. (2017) Britain's Demographic Challenge. [pdf]. pp.xii. Available at: https://www.civitas.org.uk/content/files/britainsdemographicchallengeweb.pdf

[Accessed 3 Dec. 2019].

Cobo, M.J., López-Herrera, A.G., Herrera-Viedma, E. and Herrera-Viedma, F. (2011) Science Mapping Software Tools: Review, Analysis, and Cooperative Study Among Tools, Journal of the American Society for Information Science and Technology, Vol. 62, No. 7, pp. 1382 - 1402. DOI: https://doi.org/10.1002/asi.21525 
Companies House. (2019). [online]. David Wilson Homes Limited. Available at: https://beta.companieshouse.gov.uk/company/00830271 [Accessed 2 Dec. 2019].

Construction Magazine UK. (2019). Addressing the skills shortage gap in the construction sector. [online]. Available at: https://constructionmaguk.co.uk/addressing-the-skillsshortage-gap-in-the-construction-sector/ [Accessed 2 Dec. 2019].

Construction Methods Modular. (2018). [pdf] Building Magazine, pp.1-3. Available at: https://www.buildoffsite.com/content/uploads/2018/07/Unlocking-the-Potential-ofModular-Construction_Building-FINAL-by-Anilea.pdf [Accessed 5 Nov. 2019].

Crane, H. (2019). The modular model: Can factory-built homes solve the housing crisis? [online] Available at: https://www.cityam.com/the-modular-model-can-factory-builthomes-solve-the-housing-crisis/ [Accessed 9 April. 2020].

CRL. (2018). Advantages and Disadvantages of Modular Construction | CRL. [online] Available at: https://c-r-l.com/content-hub/article/modular-construction/ [Accessed 4 Nov. 2019].

Curtis, S. (2018). Can modular homes solve the UK's housing crisis? | Strutt \& Parker. [online] Strutt and Parker. Available at: https://www.struttandparker.com/knowledge-andresearch/can-modular-homes-solve-the-uks-housing-crisis [Accessed 26 Nov. 2019].

Davies, A. (2018). Modern Methods of Construction. [pdf] RICS, pp.18-24. Available at: https://www.rics.org/globalassets/rics-website/media/news/news--opinion/modernmethods-of-construction-paper-rics.pdf [Accessed 4 Nov. 2019].

Dixon, C., Edwards, D.J., Lai, H.K., Garcia-Mateo, M., Thwala, W.D., and Shelbourne, M. (2020) An investigation into the erroneous access and egress behaviours of building users and their impact upon building performance. Facilities. DOI: https://doi.org/10.1108/F05-2019-0053

Dunton, J. (2019). MHCLG 'way off track' on 300,000-a-year homes target, say MPs | Civil Service World. [online] Civilserviceworld.com. Available at: https://www.civilserviceworld.com/articles/news/mhclg-\%E2\%80\%98waytrack\%E2\%80\%99-300000-year-homes-target-say-mps [Accessed 3 Nov. 2019].

Edenhall (2017). Technical Manual for Bricks. [pdf] pp.14. Available at: https://www.edenhall.co.uk/documents/range-brochures/technical-manual/edenhalltechnical-brochure-online-compressed-2052.pdf [Accessed 5 Dec. 2019]. 
Edwards, D. J., Holt, G. D. and Harris, F. C. (1998) Predictive maintenance techniques and their relevance to construction plant. Journal of Quality in Maintenance Engineering, Vol. 4, No. 1, pp. 25-37. DOI: https://doi.org/10.1108/13552519810369057

Edwards, D. J., Harris, F. C. and McCaffer, R. (2003) Management of off-highway plant and equipment. London: Spon. ISBN 0-415-25127-3

Edwards, D. J., Pärn, E. A., Love, P. E. D. and El-Gohary, H. (2017) Machinery, manumission and economic machinations. Journal of Business Research, Vol. 70, pp. 391-394. DOI: https://doi.org/10.1016/i.jbusres.2016.08.012

Edwards, D. J., Pärn, E. A., Sing, C. P. and Thwala, W.D. (2019) Risk of excavators overturning: determining horizontal centrifugal force when slewing freely suspended loads. Engineering, Construction and Architectural Management. 26(3), pp. 479-498. DOI: https://doi.org/10.1108/ECAM-03-2018-0125

Edwards, D.J., Rillie, I., Chileshe, N. Lai, J., Hossieni , M. Reza, and Thwala, W.D. (2020) A field survey of hand-arm vibration exposure in the UK utilities sector, Engineering, Construction and Architectural Management. DOI: https://doi.org/10.1108/ECAM-092019-0518

Elliott. (2019). Modern methods of modular construction - news | ELLIOTT UK. [online] Available at: https://www.elliottuk.com/news/modern-methods-modular-construction [Accessed 2 Nov. 2019].

Elsevier. (2019). About Scopus. [online]. Available at: https://www.elsevier.com/engb/solutions/scopus [Accessed 8 Dec. 2019].

Experian. (2018). UK Construction Forecast. [pdf] pp.18-20. Available at: https://www.experian.co.uk/assets/economics/samples/uk-construction-forecastsample.pdf [Accessed 8 April. 2020].

Fewins, C. (2019). The Pros and Cons of Different Construction Systems. [pdf] pp.3-4. Available at: https://www.cyprus-property-buyers.com/files/constructionmethods.pdf [Accessed 30 Nov. 2019].

Frigione, M., Lettieri, M. and Sarcinella, A. (2019). Phase Change Materials for Energy Efficiency in Buildings and their use in Mortars, Materials (Basel), Vol. 12, No. 8. DOI: https://doi.org/10.3390/ma12081260

Glenigan. (2019). Construction $2025 \quad$ Glenigan. [online] Available at: https://www.glenigan.com/construction-2025/ [Accessed 1 Dec. 2019]. 
Golawski, P. (2018). Advantages and disadvantages of modular homes. [online] Medium. Available at: https://medium.com/@piotrgoawski/advantages-and-disadvantages-ofmodular-homes-3592799ea [Accessed 4 Nov. 2019].

GOV.UK. (2019). Construction Sector Deal. [online] Available at: https://www.gov.uk/government/publications/construction-sector-deal/constructionsector-deal [Accessed 3 Nov. 2019].

Green, B. (2016). Productivity in construction: Creating a framework for the industry to thrive. [pdf] pp.13. Available at: https://policy.ciob.org/wp-content/uploads/2016/05/CIOBProductivity-report-2016-v4_single.pdf [Accessed 1 Dec. 2019].

Greenhoot, A. and Dowsett, C. (2012). Secondary Data Analysis: An Important Tool for Addressing Developmental Questions, Journal of Cognition and Development, Vol. 13, No. 1, pp 2-18. DOI: https://doi.org/10.1080/15248372.2012.646613

Historic England. (2019). BIM for Heritage - Developing the Asset Information Model. [pdf] pp.9-11. Available at: https://historicengland.org.uk/images-books/publications/bimfor-heritage-aim/heag271-bim-developing-asset-info-model/ [Accessed 10 Nov. 2019].

Hooper, T. (2019). Policy position - Modern Methods of Construction. [online]. Available: https://www.rics.org/uk/news-insight/latest-news/press-releases/modern-methods-ofconstruction/ [Accessed 22 Nov. 2019].

Hudson, N. (2018). A HOUSING CRISIS? More like a series of local crises needing local solutions. $\quad[\mathrm{pdf}] \quad$ p.5. Available at: http://resi-analysts.com/wpcontent/uploads/2018/11/A-Housing-Crisis-2018-10-15-v3.pdf [Accessed 2 Dec. 2019].

Hyams, A. (2016). Cost model: Affordable housing. [online]. Available at: https://www.building.co.uk/main-navigation/cost-model-affordablehousing/5082032.article [Accessed 1 Nov. 2019].

Ibstock Brick. (2019). Oakwell Grange, London. [online]. Available at: https://ibstockbrick.co.uk/case-studies/oakwell-grange/ [Accessed 1 Dec. 2019].

Jin, R., Zou, P.X.W., Piroozfar, P., Wood, H., Yang, Y., Yan, L. and Han, Y. (2019) A Science Mapping Approach Based Review of Construction Safety Research, Safety Science, Vol. 113, pp. 285-297. DOI: https://doi.org/10.1016/j.ssci.2018.12.006

John, A.O and Itodo, D.E. (2013). Professional's views of material wastage on construction sites and cost overruns. [online]. Available at: https://www.academia.edu/3774172/Professionals_Views_of_Material_Wastage_on_C onstruction_Sites_and_Cost_Overruns [Accessed: 5 Dec. 2019]. 
KPMG. (2019). Smart construction - How offsite manufacturing can transform our industry. [pdf] KPMG. Available at: https://assets.kpmg/content/dam/kpmg/pdf/2016/04/SmartConstructionReport.pdf [Accessed 23 Nov. 2019].

LABC. (2019). Modern methods of construction in social housing - the challenges. [online]. Available at: https://www.labcwarranty.co.uk/blog/modern-methods-of-construction-insocial-housing-the-challenges/ [Accessed 10 Dec. 2019].

Lawson, R.M. and Ogden, R.G. (2014). Sustainability and Process Benefits of Modular Construction. $\quad$ [pdf] $47 . \quad$ Available at: https://www.irbnet.de/daten/iconda/CIB18783.pdf [Accessed 21 Nov. 2019].

Legal and General Group. (2014). Let's House Britain. [pdf]. UK Housing Crisis Report, pp.3. Available: https://www.legalandgeneralgroup.com/media/1091/lets_house_britain.pdf [Accessed 2 Nov. 2019].

Leppänen, A. (2019). Modern Methods of Construction: Building more homes, better and faster. [online]. Available at: https://www.centreforlondon.org/blog/modern-methodsof-construction/ [Accessed 8 April 2020].

London Assembly. (2017). Designed, sealed, delivered; The contribution of offsite manufactured homes to solving London's housing crisis. [pdf] pp. 15. Available at: https://www.london.gov.uk/moderngov/documents/s67697/07b\%20\%20Appendix\%201\%20-\%20Rapporteur\%20Report.pdf [Accessed 9 April. 2020].

Mills, F. (2016). Construction 2025 Explained. [online] Theb1m.com. Available at: https://www.theb1m.com/video/construction-2025-explained [Accessed 1 Dec. 2019].

Ministry of Housing, Communities \& Local Government. (2018). A new deal for social housing. [pdf] Available at: https://assets.publishing.service.gov.uk/government/uploads/system/uploads/attachment _data/file/733605/A_new_deal_for_social_housing_web_accessible.pdf [Accessed 24 Nov. 2019].

Ministry of Housing, Communities and Local Government. (2017). Fixing our broken housing market. [pdf] Open Government License, pp.9-10. Available at: https://assets.publishing.service.gov.uk/government/uploads/system/uploads/attachment _data/file/590463/Fixing_our_broken_housing_market_-_accessible_version.pdf [Accessed 3 Nov. 2019].

Modular Today. (2019). History of Modular Homes \& Buildings. [online] Available at: https://www.modulartoday.com/modular-history.html [Accessed 2 Nov. 2019]. 
MTC. (2019). Standardised Component Sets. [pdf] pp.1. Available at: https://www.google.co.uk/url?sa=t\&rct=j\&q=\&esrc=s\&source=web\&cd=10\&ved=2ah UKEwj28oLCk7DmAhW1RxUIHVN7AZMQFjAJegQIBhAC\&url=http\%3A\%2F\%2F www.themtc.org\%2F_literature_152526\%2FStandardised_component_sets_i3P_discovery_proj ect_poster\&usg=AOvVaw2vSfdWoZZkDExxMJhb6V4d [Accessed 12 Dec. 2019].

MTX. (2017). Modular Vs. Traditional Construction. [online] MTX. Available at: https://www.mtxcontracts.co.uk/modular-vs-traditional-construction/ [Accessed 4 Nov. 2019].

Mulheirn, I. (2019). Why building 300,000 houses per year won't solve the housing crisis and what will. [online]. Available at: https://blogs.lse.ac.uk/politicsandpolicy/tacklingthe-uk-housing-crisis/ [Accessed 8 April. 2020].

Muresan, F. (2019). Masonry Construction: Advantages and Disadvantages. [online] Nyengineers. Available at: https://www.ny-engineers.com/blog/masonry-constructionadvantages-and-disadvantages [Accessed 16 Nov. 2019].

Nawi, MNM, Hanifa, FAA, Kamar, KAM, Lee, A and Azman and MNA (2014). Modern method of construction: an experience from UK construction industry, Australian Journal of Basic and Applied Sciences, Vol. 8, No. 5, pp. 527-532. Available at: http://usir.salford.ac.uk/49772/ [Accessed 4 Nov. 2019].

Nawi, M., Baluch, N. and Bahauddin, A. (2014). Impact of Fragmentation Issue in Construction Industry: An Overview, Building Surveying, Facilities Management and Engineering Conference (BSFMEC 2014), 27 August 2014, Perak, Malaysia. Available at: https://www.matecconferences.org/articles/matecconf/pdf/2014/06/matecconf_bsfmec2014_01009.pdf [Accessed 25 Nov. 2019]. DOI: 10.1051/matecconf/20141501009

NEC4. (2018). Offsite modular construction. [pdf] pp.3. Available at: https://www.neccontract.com/getmedia/234a23f1-6736-4785-8aaba07af58789e1/Practice-Note-4_finalweb [Accessed 7 Dec. 2019].

Newman, C., Edwards, D.J., Martek, I., Lai, J. and Thwala, W.D. (2020) Industry 4.0 Deployment in the Construction Industry: A Bibliometric Literature Review and UKbased Case Study, Smart and Sustainable Built Environment. Vol. ahead-of-print No. ahead-of-print. DOI: https://doi.org/10.1108/SASBE-02-2020-0016 
NHBC Foundation. (2016). Modern methods of construction - views from the industry. [pdf] pp.4-9. Available at: https://www.buildoffsite.com/content/uploads/2016/07/NF70MMC-WEB.pdf [Accessed 5 Nov. 2019].

NHBC Foundation (2018). Modern methods of construction - Who's doing what?. [pdf] pp.21. Available at: https://www.nhbcfoundation.org/wp-content/uploads/2018/11/NF82.pdf [Accessed 15 Nov. 2019].

Oliveira, S., Burch, J., Hutchison, K., Adekola, O., Jaradat, S. and Jones, M. (2019). Making Modular Stack Up: Modern Methods Of Construction In Social Housing. [pdf] pp.19-22. Available at: https://www.flagship-group.co.uk/media/1921/full-report-final.pdf [Accessed 1 Dec. 2019].

ONS. (2019). Construction statistics, Great Britain - Office for National Statistics. [online] Available at: https://www.ons.gov.uk/businessindustryandtrade/constructionindustry/articles/constru ctionstatistics/2018 [Accessed 13 Nov. 2019].

Ons.gov.uk. (2019). Construction output in Great Britain - Office for National Statistics. [online] Available at: https://www.ons.gov.uk/businessindustryandtrade/constructionindustry/bulletins/constr uctionoutputingreatbritain/august2019 [Accessed 3 Nov. 2019].

Open Government Licence. (2018). Industrial Strategy. [pdf] pp.37. Available at: https://assets.publishing.service.gov.uk/government/uploads/system/uploads/attachment _data/file/731871/construction-sector-deal-print-single.pdf [Accessed 8 April. 2020].

Pitts, M. (2019). Transforming construction - Innovate UK. [online] Innovateuk.blog.gov.uk. Available at: https://innovateuk.blog.gov.uk/2018/07/06/transforming-construction/ [Accessed 2 Nov. 2019].

Planning, BIM \& Construction Today. (2019). RICS report urges government to adopt Modern Methods of Construction. [online] Available at: https://www.pbctoday.co.uk/news/modular-construction-news/rics-report-mmc/56231/ [Accessed 1 Dec. 2019].

Rahman, M. (2014). Barriers of Implementing Modern Methods of Construction, Journal of Management in Engineering, Vol. 30, No. 1. DOI: https://doi.org/10.1061/(ASCE)ME.1943-5479.0000173

Reds 10. (2015). Modular vs Traditional Construction - Reds10. [online] Available at: https://www.reds10.com/2015/08/31/modular-vs-traditional-construction/ [Accessed 11 Nov. 2019]. 
Research-Methodology (2019). Interpretivism (interpretivist) Research Philosophy - ResearchMethodology. [online] Research-Methodology. Available at: https://researchmethodology.net/research-philosophy/interpretivism/ [Accessed 12 Dec. 2019].

Rhodes, C. (2018). Construction industry: statistics and policy. House of Commons Library, pp.3-5. Available from: www.researchbriefings.files.parliment.uk [Accessed 31 October 2019].

Riaz, Z., Edwards, D. J. and Thorpe, A. (2006) SightSafety: A hybrid information and communication technology system for reducing vehicle/pedestrian collisions. Automation in Construction, Vol. 15, No. 6, pp. 719 - 728. DOI: https://doi.org/10.1016/j.autcon.2005.09.004

Roberts, C. J., Edwards, D. J., Hosseini, M. Reza., Matzeo-Garcia, M. and Owusu-Man, D. (2019) Post occupancy evaluation: a critical review of literature. Engineering, Construction and Architectural Management. Vol. 26, No. 9, pp. 2084-2106. DOI: https://doi.org/10.1108/ECAM-09-2018-0390

Romei, V. (2019). UK construction activity 'drops like a stone' to decade low | Financial Times. [online] Ft.com. Available at: https://www.ft.com/content/fa499cb0-9ca5-11e9b8ce-8b459ed04726 [Accessed 1 Nov. 2019].

Root III, G. (2019). The Disadvantages of Using Brick to Build Houses. [online] Hunker. Available at: https://www.hunker.com/13401376/the-disadvantages-of-using-brick-tobuild-houses [Accessed 15 Nov. 2019].

Saunders, M., Lewis, P. and Thornhill, A. (2009). Understanding research philosophies and approaches, In: Saunders, Mark N. K.; Lewis, Philip and Thornhill, Adrian eds. Research Methods for Business Students, 8th edition. Harlow: Pearson Education, pp. 128-171. ISBN: 1-292-20878-3, 978-1-292-20878-7

Shelter. (2019). A vision for social housing. [pdf] Shelter, p.4. Available at: https://england.shelter.org.uk/_data/assets/pdf_file/0004/1642612/Shelter_UK__A_vision_for_social_housing_executive_summary.pdf [Accessed 16 Nov. 2019].

STBA. (2012) Responsible Retrofit of Traditional Buildings. [pdf] pp.20-22. Available at: http://www.ihbc.org.uk/recent_papers/docs/STBAresponsible_retrofit2012.pdf [Accessed 5 Nov. 2019].

Stubbs, B. (2008). Plain English Guide to Sustainable Construction. [pdf] Available at: http://constructingexcellence.org.uk/wpcontent/uploads/2015/02/SUSTAINGUIDE.pdf [Accessed 24 Nov. 2019]. 
The Self Build Guide. (2019). Why choose masonry construction? - The Self Build Guide. [online] Available at: https://www.the-self-build-guide.co.uk/masonry-construction/ [Accessed 5 Nov. 2019].

UCL. (2019). Meeting Paul Hackett: we talk solutions for affordable housing with our new Honorary Professor. [online]. Available at: https://www.ucl.ac.uk/bartlett/construction/news/2019/may/meeting-paul-hackett-wetalk-solutions-affordable-housing-our-new-honorary-professor [Accessed 2 Nov. 2019].

UK Construction Media. (2019). Onwards and upwards: Modular Construction - UK Construction

Online. [online] Available at: https://www.ukconstructionmedia.co.uk/features/modular-construction-onwardsupwards/ [Accessed 1 Nov. 2019].

Van Eck, N. J. and Waltman, L. (2010) Software survey: VOSviewer, a computer program for bibliometric mapping, Scientometrics, Vol. 84, No. 2., pp. 523-538. DOI: https://doi.org/10.1007/s11192-009-0146-3

Williams, K. (2018). Innovation - Exploring Hostile Environments - A Northern Education Modular Housing. Pp.2-3. Available from: $\underline{\text { http://multipoint- }}$ foundations.com/docs/Innovation-March_April-2018.pdf [Accessed 26 Nov. 2019].

Wrap. (2007). Current Practices and Future Potential in Modern Methods of Construction. $\begin{array}{llll}\text { [pdf] } & \text { pp.7. } & \text { Available }\end{array}$ http://www.wrap.org.uk/sites/files/wrap/Modern\%20Methods\%20of\%20Construction \%20-\%20Summmary.pdf [Accessed 9. April 2020].

Wrap. (2019). Reducing your construction waste. [pdf] pp.2. Available at: http://www.wrap.org.uk/sites/files/wrap/Reducing\%20your\%20construction\%20waste \%20-\%20a\%20pocket\%20guide\%20for\%20SME\%20contractors.pdf [Accessed 4 Dec. 2019].

Yalcinkaya, M. and Singh, V. (2015) Patterns and trends in Building Information Modeling (BIM) research: A Latent Semantic Analysis, Automation in Construction, Vol. 59. pp. 68-80. DOI: http://dx.doi.org/10.1016/j.autcon.2015.07.012

Yisa, S.B., Ndekugri, I. and Ambrose, B. (1996), "A review of changes in the UK construction industry: Their implications for the marketing of construction services", European Journal of Marketing, Vol. 30 No. 3, pp. 47-64. DOI: https://doi.org/10.1108/03090569610107427 
Zhao, X. and Riffat, S. (2019). Prefabrication in house constructions, International Journal of Low-Carbon Technologies, Vol. 2, No. 1, pp. 44-51. DOI: https://doi.org/10.1093/ijlct/2.1.44 
Table 1 - Chronological distribution of publications over the period 1990 to 2019

\begin{tabular}{|c|c|c|}
\hline YEAR & FREQUENCY (Nr) & PERCENTAGE (\%) \\
\hline 1990 & 0 & 0.00 \\
\hline 1991 & 0 & 0.00 \\
\hline 1992 & 0 & 0.00 \\
\hline 1993 & 1 & 1.37 \\
\hline 1994 & 2 & 2.74 \\
\hline 1995 & 1 & 1.37 \\
\hline 1996 & 0 & 0.00 \\
\hline 1997 & 1 & 1.37 \\
\hline 1998 & 1 & 1.37 \\
\hline 1999 & 0 & 0.00 \\
\hline 2000 & 0 & 0.00 \\
\hline 2001 & 0 & 0.00 \\
\hline 2002 & 0 & 0.00 \\
\hline 2003 & 1 & 1.37 \\
\hline 2004 & 2 & 2.74 \\
\hline 2005 & 2 & 2.74 \\
\hline 2006 & 5 & 6.85 \\
\hline 2007 & 2 & 2.74 \\
\hline 2008 & 3 & 4.11 \\
\hline 2009 & 2 & 2.74 \\
\hline 2010 & 5 & 6.85 \\
\hline 2011 & 4 & 5.48 \\
\hline 2012 & 7 & 9.59 \\
\hline 2013 & 5 & 6.85 \\
\hline 2014 & 3 & 4.11 \\
\hline 2015 & 5 & 6.85 \\
\hline 2016 & 6 & 8.22 \\
\hline 2017 & 6 & 8.22 \\
\hline 2018 & 5 & 6.85 \\
\hline 2019 & 3 & 4.11 \\
\hline
\end{tabular}


Table 2 - UK's Construction industry compared against the rest of Europe

\begin{tabular}{|c|c|c|c|c|c|c|}
\hline \multicolumn{7}{|c|}{ UNIT: INDEX } \\
\hline YEAR & UK & Germany & Spain & France & Italy & $\begin{array}{c}\text { Euro area } \\
\quad(19 \\
\text { countries })\end{array}$ \\
\hline 2009 & 84.9 & 93.2 & 136.5 & 114.6 & 152.4 & 116.1 \\
\hline 2010 & 91.5 & 92.4 & 108.7 & 111.8 & 147 & 109.9 \\
\hline 2011 & 92.8 & 99.1 & 87.2 & 109.9 & 140.5 & 108.4 \\
\hline 2012 & 86 & 99.1 & 82.5 & 104.3 & 121.8 & 102.7 \\
\hline 2013 & 87.4 & 99 & 83.7 & 104.8 & 109.3 & 100.2 \\
\hline 2014 & 96.2 & 101.9 & 98.3 & 102 & 101.8 & 100.8 \\
\hline 2015 & 100 & 99.6 & 100 & 100 & 100 & 100 \\
\hline 2016 & 103.9 & 105.2 & 105.1 & 99.8 & 99.9 & 102.7 \\
\hline 2017 & 110.1 & 108.7 & 103.6 & 102.7 & 100.6 & 105.6 \\
\hline 2018 & 110.2 & 109 & 106 & 102.3 & 101.6 & 107.4 \\
\hline
\end{tabular}

(Source: ONS, 2019) 
Table 3 - UK government aims to be realized by 2025

\begin{tabular}{|c|c|c|}
\hline FACTOR & AIM & CITATIONS \\
\hline $\begin{array}{l}\text { Costs (Initial \& Whole Life } \\
\text { Cost) }\end{array}$ & An overall reduction of $33 \%$ & (Rhodes, 2018) \\
\hline $\begin{array}{l}\text { Time (From Inception to } \\
\text { Completion) }\end{array}$ & $\begin{array}{l}\text { Based on industry standards in } 2013 \text {, an } \\
\text { overall decrease of } 50 \% \text { is targeted }\end{array}$ & (Rhodes, 2018) \\
\hline Greenhouse Gas Emissions & $\begin{array}{l}\text { To reduce emissions around } 50 \% \text { in the } \\
\text { built environment sector }\end{array}$ & (Rhodes, 2018) \\
\hline Trade Gap & $\begin{array}{l}\text { Target of } 50 \% \text { cutback between total } \\
\text { imports/exports of materials/products }\end{array}$ & (Rhodes, 2018) \\
\hline
\end{tabular}

(Source: Rhodes, 2018) 
Table 4 - New orders fall in 2018 for the first time in the UK since 2011

\begin{tabular}{|c|c|c|c|c|c|c|c|}
\hline \multirow[t]{2}{*}{ Unit } & & \multicolumn{6}{|l|}{ £ million } \\
\hline & & $\begin{array}{l}\text { Public } \\
\text { housing }\end{array}$ & $\begin{array}{l}\text { Private } \\
\text { industrial }\end{array}$ & $\begin{array}{l}\text { Public } \\
\text { other new } \\
\text { work }\end{array}$ & $\begin{array}{l}\text { Infra- } \\
\text { structure }\end{array}$ & $\begin{array}{l}\text { Private } \\
\text { commercia } \\
\text { l }\end{array}$ & $\begin{array}{l}\text { Private } \\
\text { housing }\end{array}$ \\
\hline & 2011 & 2691 & 2145 & 9065 & 8499 & 13005 & 10506 \\
\hline & 2012 & 2450 & 2659 & 8028 & 12510 & 11973 & 10805 \\
\hline & 2013 & 3990 & 3604 & 9062 & 10819 & 13563 & 14575 \\
\hline & 2014 & 2034 & 3934 & 9841 & 9666 & 16916 & 16627 \\
\hline & 2015 & 1581 & 4994 & 7793 & 14819 & 16690 & 16774 \\
\hline & 2016 & 2020 & 4619 & 8500 & 15423 & 17737 & 17826 \\
\hline & 2017 & 1745 & 4905 & 7437 & 20991 & 16656 & 19253 \\
\hline & 2018 & 1316 & 5094 & 8161 & 11544 & 15224 & 20313 \\
\hline
\end{tabular}

(Source: ONS, 2019) 
Table 5 - Social Housing Affordability Bands (Under-40 households by region - 2015)

\begin{tabular}{|c|c|c|c|c|}
\hline REGION & BAND & OWN & SOCIAL & $\begin{array}{l}\text { PRIVATE } \\
\text { RENT }\end{array}$ \\
\hline NORTH & $\begin{array}{l}\text { Can Buy } \\
\text { Market Rent } \\
\text { Social Rent }\end{array}$ & $\begin{array}{l}75 \% \\
4 \% \\
17 \%\end{array}$ & $\begin{array}{l}23 \% \\
28 \% \\
45 \%\end{array}$ & $\begin{array}{l}43 \% \\
5 \% \\
47 \%\end{array}$ \\
\hline SOUTH & $\begin{array}{l}\text { Can Buy } \\
\text { Market Rent } \\
\text { Social Rent }\end{array}$ & $\begin{array}{l}65 \% \\
9 \% \\
21 \%\end{array}$ & $\begin{array}{l}9 \% \\
28 \% \\
54 \%\end{array}$ & $\begin{array}{l}36 \% \\
13 \% \\
38 \%\end{array}$ \\
\hline MIDLANDS & $\begin{array}{l}\text { Can Buy } \\
\text { Market Rent } \\
\text { Social Rent }\end{array}$ & $\begin{array}{l}79 \% \\
4 \% \\
14 \%\end{array}$ & $\begin{array}{l}22 \% \\
34 \% \\
44 \%\end{array}$ & $\begin{array}{l}43 \% \\
11 \% \\
37 \%\end{array}$ \\
\hline $\begin{array}{l}\text { GREATER } \\
\text { LONDON }\end{array}$ & $\begin{array}{l}\text { Can Buy } \\
\text { Market Rent } \\
\text { Social Rent }\end{array}$ & $\begin{array}{l}42 \% \\
27 \% \\
20 \%\end{array}$ & $\begin{array}{l}1 \% \\
44 \% \\
41 \%\end{array}$ & $\begin{array}{l}13 \% \\
10 \% \\
47 \%\end{array}$ \\
\hline
\end{tabular}

(Source: Bramley, 2018) 
Table 6 - Advantages and Disadvantages of Traditional Masonry Construction

\begin{tabular}{|c|c|c|}
\hline ADVANTAGES & DESCRIPTION & CITATIONS \\
\hline $\begin{array}{ll}\text { Availability } & \text { of } \\
\text { Materials } & \end{array}$ & $\begin{array}{l}\text { Materials are manufactured and sourced locally, meaning } \\
\text { availability is provided openly. }\end{array}$ & $\begin{array}{l}\text { (The Self Build } \\
\text { Guide, 2019) }\end{array}$ \\
\hline Thermal Performance & $\begin{array}{l}\text { Due to high thermal mass in the materials to absorb and store } \\
\text { heat, this allows houses during the summer period to be kept in } \\
\text { a cool temperature whilst during winter heat is stored during the } \\
\text { day. }\end{array}$ & $\begin{array}{l}\text { (The Self Build } \\
\text { Guide, 2019) }\end{array}$ \\
\hline Popularity & $\begin{array}{l}\text { As this is the most common form of house construction in the } \\
\text { UK, the accessibility of skilled workers is high for any } \\
\text { residential projects needed. }\end{array}$ & (Bridgen, 2013) \\
\hline $\begin{array}{l}\text { Durability alongside } \\
\text { flexibility }\end{array}$ & $\begin{array}{l}\text { Houses that were built centuries ago are still standing in many } \\
\text { parts of the UK, and they are able to withstand severe } \\
\text { weather/temperatures. This leads to very less maintenance over } \\
\text { their whole lifecycle as bricks are not in need of paint or sealant } \\
\text { to maintain their appearance. }\end{array}$ & (Bridgen, 2013) \\
\hline DISADVANTAGES & DESCRIPTION & CITATIONS \\
\hline $\begin{array}{lr}\text { Slower } & \text { process } \\
\text { alongside } & \text { weather } \\
\text { conditions impact }\end{array}$ & $\begin{array}{l}\text { On average, it takes } 20 \text { weeks or more to build in masonry. The } \\
\text { form is of wet construction meaning more time is desired to } \\
\text { completely dry out at several intervals. Masonry cannot be laid } \\
\text { when it is raining heavily or when temperatures fall below } \\
\text { freezing. This is where alternative methods such as modular } \\
\text { construction fits in, since the process is completed in a factory- } \\
\text { based environment. }\end{array}$ & $\begin{array}{l}\text { (Bridgen, 2013) } \\
\text { (Fenwins, 2019) }\end{array}$ \\
\hline $\begin{array}{l}\text { Occurrence of } \\
\text { dampness (Spalling) }\end{array}$ & $\begin{array}{l}\text { Unintended bridges may form and allow damp to seep through } \\
\text { the inner skin of the wall, if large amounts of mortar fall on the } \\
\text { cavity ties above the damp-proof course. This will cause limited } \\
\text { energy efficiency ratings. When moisture from rainfall, melting } \\
\text { snow, or soil enters bricks, it can freeze and thaw causing } \\
\text { spalling. Cracks eventually increase in size that will eventually } \\
\text { lead to crumbling. }\end{array}$ & $\begin{array}{l}\text { (Brick } \\
\text { 2019) }\end{array}$ \\
\hline High building costs & $\begin{array}{l}\text { Building with bricks is commonly considered rather extravagant } \\
\text { due to the need for more building materials. Depending on the } \\
\text { actual manufacturing process and time of purchase, costs per } \\
\text { brick varies from } £ 300 \text { - } £ 1200 \text { per } 1000 \text { bricks. }\end{array}$ & $\begin{array}{l}\text { (Brick hunter, } \\
\text { 2019) }\end{array}$ \\
\hline $\begin{array}{l}\text { Whole } \\
\text { Performance }\end{array}$ & $\begin{array}{l}\text { The multiple limitations of model-based assessments of } \\
\text { traditional buildings means that a gap is frequently identified } \\
\text { between modelled assessments and the monitored realities of } \\
\text { traditional building performance. In addition, Traditional } \\
\text { buildings are not well served by current buildings energy } \\
\text { assessment models; this is of significant concern given the } \\
\text { prevalence of modelling within the disciplines that guide } \\
\text { construction practices, including overarching policy decisions. }\end{array}$ & $($ STBA, 2012) \\
\hline
\end{tabular}


Table 7 - Advantages and Disadvantages of Modular Housing Construction

\begin{tabular}{|c|c|c|}
\hline ADVANTAGES & DESCRIPTION & CITATIONS \\
\hline $\begin{array}{l}\text { Quicker construction } \\
\text { method }\end{array}$ & $\begin{array}{l}\text { Quicker Construction: Modular homes are faster to } \\
\text { build due to the use of a continuous operating assembly } \\
\text { line. In addition, each building component is checked as } \\
\text { they become ready instead of needing to wait for a city } \\
\text { inspector to sign everything off which is time- } \\
\text { consuming. Up to } 50 \% \text { time-savings compared to the } \\
\text { traditional method, with an average construction time of } \\
180 \text { days. Greater repeatability, automation and } \\
\text { collaborations ensures house completions to be built in } \\
\text { approximately less than two months at the factory. }\end{array}$ & $\begin{array}{l}\text { (CRL, 2018; MTX, 2017; } \\
\text { Golawski, 2018) }\end{array}$ \\
\hline Cost-effective & $\begin{array}{l}\text { Due to its affordability as several units are constructed } \\
\text { at once therefore economies of scale are in effect. } \\
\text { Savings between } 10 \%-20 \% \text { are achieved through the } \\
\text { use of modular techniques. }\end{array}$ & (CRL, 2018; MTX, 2017) \\
\hline $\begin{array}{l}\text { Reduced energy } \\
\text { consumption }\end{array}$ & $\begin{array}{l}\text { During the actual building process this is reduced } \\
\text { around } 67 \% \text {. }\end{array}$ & (MTX, 2017) \\
\hline $\begin{array}{l}\text { Better durability \& } \\
\text { quality houses }\end{array}$ & $\begin{array}{l}\text { Drawings are much more detailed compared to } \\
\text { traditional where every single detail is elaborated as } \\
\text { well as a higher health and safety level in the factory } \\
\text { minimises risks, leading to better durability. }\end{array}$ & (Golawski, 2018) \\
\hline DISADVANTAGES & DESCRIPTION & CITATIONS \\
\hline Flexibility & $\begin{array}{l}\text { the space planning, detailed design and service } \\
\text { integration all need to be completed earlier compared to } \\
\text { traditional projects. Incorporating late design variations } \\
\text { to the modules will cause high costs. }\end{array}$ & $\begin{array}{l}\text { (Construction Methods } \\
\text { Modular, 2018). }\end{array}$ \\
\hline Industry-related issues & $\begin{array}{l}\text { Due to the requirement of frequent communication and } \\
\text { effective coordination between the involved parties, the } \\
\text { fragmented nature of the construction industry these } \\
\text { factors making it difficult to standardize designs for the } \\
\text { modular method. }\end{array}$ & (Rahman, 2014). \\
\hline Procurement & $\begin{array}{l}\text { A thorough choice of supplier to develop a close } \\
\text { relationship is crucial, because once engaged there is } \\
\text { usually very little scope to source modules from an } \\
\text { alternative company, if the original supplier fails to } \\
\text { perform. }\end{array}$ & $\begin{array}{l}\text { (Construction Methods } \\
\text { Modular, 2018). }\end{array}$ \\
\hline $\begin{array}{l}\text { Lack } \\
\text { skills/experience } \\
\text { needed }\end{array}$ & $\begin{array}{l}\text { The requirement for highly skilled labor for both } \\
\text { producing parts/modules of the houses in factories and } \\
\text { the precision of on-site assembly of parts is needed. } \\
\text { Generally, many workers in the construction industry } \\
\text { have had little or no experience with modular } \\
\text { construction, which emphasis on the fact that university } \\
\text { level students are not receiving enough materials to } \\
\text { learn about the modern method concept. }\end{array}$ & (Rahman, 2014). \\
\hline
\end{tabular}


Table 8 - In-depth cost comparison between a modular housing cost model to affordable housing (traditional method)

\begin{tabular}{|c|c|c|c|c|c|}
\hline $\begin{array}{l}\text { SHELL AND CORE } \\
\text { WORKS }\end{array}$ & $\begin{array}{l}\text { MODULAR } \\
\text { HOUSING }\end{array}$ & $\mathfrak{f} / \mathbf{m} 2$ & $\begin{array}{l}\text { TRADTIONAL } \\
\text { AFFORDABLE } \\
\text { HOUSING }\end{array}$ & $\mathfrak{f} / \mathbf{m} 2$ & $\begin{array}{l}\text { Cost } \\
\text { Difference }\end{array}$ \\
\hline Substructure & $£ 897,970.00$ & $£ 60.22$ & $£ 3,664,360.00$ & $£ 203.00$ & $£ 2,766,390.00$ \\
\hline Frame and Upper Floors & $£ 694,800.00$ & $£ 46.60$ & $£ 4,731,810.00$ & $£ 263.00$ & $£ 4,037,010.00$ \\
\hline Stairs & $£ 217,000.00$ & $£ 14.55$ & $£ 726,500.00$ & $£ 41.00$ & $£ 509,500.00$ \\
\hline Roof & $£ 325,890.00$ & $£ 21.86$ & $£ 776,445.00$ & $£ 43.00$ & $£ 450,555.00$ \\
\hline $\begin{array}{l}\text { External Walls, Windows, } \\
\text { Doors and Balconies }\end{array}$ & $£ 2,130,142.00$ & $£ 142.86$ & $£ 8,236,140.00$ & $£ 457.00$ & $£ 6,105,998.00$ \\
\hline $\begin{array}{l}\text { Internal Walls, Partitions } \\
\text { and Doors }\end{array}$ & $£ 603,900.00$ & $£ 40.50$ & $£ 1,835,220.00$ & $£ 113.00$ & $£ 1,231,320.00$ \\
\hline Wall Finishes & $£ 801,194.00$ & $£ 53.73$ & $£ 1,266,746.00$ & $£ 70.00$ & $£ 465,552.00$ \\
\hline Floor Finishes & $£ 781,374.00$ & $£ 52.40$ & $£ 1,104,095.00$ & $£ 61.00$ & $£ 322,721.00$ \\
\hline Ceiling Finishes & $£ 292,894.00$ & $£ 19.65$ & $£ 679,782.00$ & $£ 38.00$ & $£ 386,888.00$ \\
\hline $\begin{array}{l}\text { Fittings, Furnishings } \quad \& \\
\text { Equipment }\end{array}$ & $£ 10,341,752.00$ & $£ 693.57$ & $£ 2,566,252.00$ & $£ 142.00$ & $-£ 7,775,500.00$ \\
\hline Sanitary Ware & $£ 508,000.00$ & $£ 34.07$ & $£ 4,975,452.00$ & $£ 276.00$ & $£ 4,467,452.00$ \\
\hline Disposal Installations & $£ 496,935.00$ & $£ 33.33$ & $£ 504,756.00$ & $£ 28.00$ & $£ 7,821.00$ \\
\hline Water Installations & $£ 608,588.00$ & $£ 40.82$ & $£ 270,405.00$ & $£ 15.00$ & $-£ 338,183.00$ \\
\hline $\begin{array}{ll}\text { Space } & \text { Heating/Air } \\
\text { Treatment } & \end{array}$ & $£ 1,262,640.00$ & $£ 84.68$ & $£ 288,432.00$ & $£ 16.00$ & $-£ 974,208.00$ \\
\hline Ventilation Installations & $£ 582,192.00$ & $£ 39.05$ & $£ 540,810.00$ & $£ 30.00$ & $-£ 41,382.00$ \\
\hline Electrical Installations & $£ 2,598,086.00$ & $£ 174.24$ & $£ 973,458.00$ & $£ 54.00$ & $-£ 1,624,628.00$ \\
\hline Gas Installations & $£ 0.00$ & $£ 0.00$ & $£ 36,054.00$ & $£ 2.00$ & - \\
\hline Heat Source & $£ 644,930.00$ & $£ 43.25$ & $£ 847,269.00$ & $£ 47.00$ & $£ 202,339.00$ \\
\hline Protective Installations & $£ 365,893.00$ & $£ 24.54$ & $£ 360,540.00$ & $£ 20.00$ & $-£ 5,353.00$ \\
\hline $\begin{array}{l}\text { Communication } \\
\text { Installations }\end{array}$ & $£ 769,491.00$ & $£ 51.61$ & $£ 666,999.00$ & $£ 37.00$ & $-£ 102,492.00$ \\
\hline Special Installations & $£ 312,738.00$ & $£ 20.97$ & $£ 432,648.00$ & $£ 24.00$ & $£ 119,910.00$ \\
\hline Lift Installations & $£ 678,000.00$ & $£ 45.47$ & $£ 901,350.00$ & $£ 50.00$ & $£ 223,350.00$ \\
\hline Builders Work & $£ 268,198.00$ & $£ 17.99$ & $£ 288,432.00$ & $£ 16.00$ & $£ 20,234.00$ \\
\hline Preliminaries/Contingencies & $£ 7,056,327.00$ & $£ 473.23$ & $£ 8,869,488.00$ & $£ 951.00$ & $£ 1,813,161.00$ \\
\hline External Works and Utilities & $£ 1,167,000.00$ & $£ 78.27$ & & & - \\
\hline TOTAL: & $\underline{£ 34,405,934.00}$ & $£ 2,307.46$ & $\underline{£ 45,543,443.00}$ & $£ 2,997.00$ & \\
\hline
\end{tabular}

(Modular cost model - Secondary Data obtained from AECOM, 2017)

(Affordable homes cost model - Secondary Data obtained from Hyams, 2016) 
Figure 1 - Collaborative networks of authors active in UK housing research

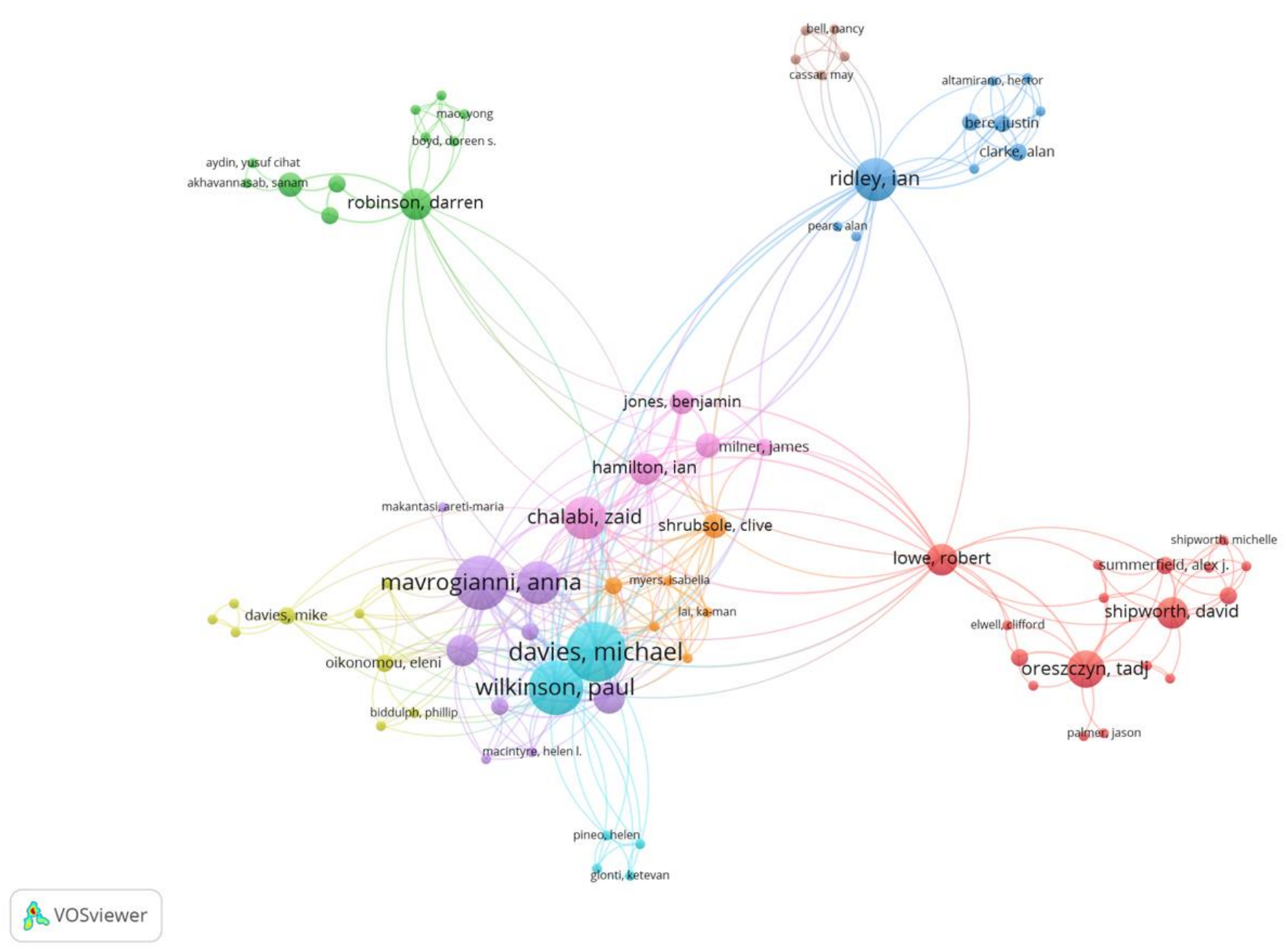


Figure 2 - Sub-theme density within the broad research topic of UK housing

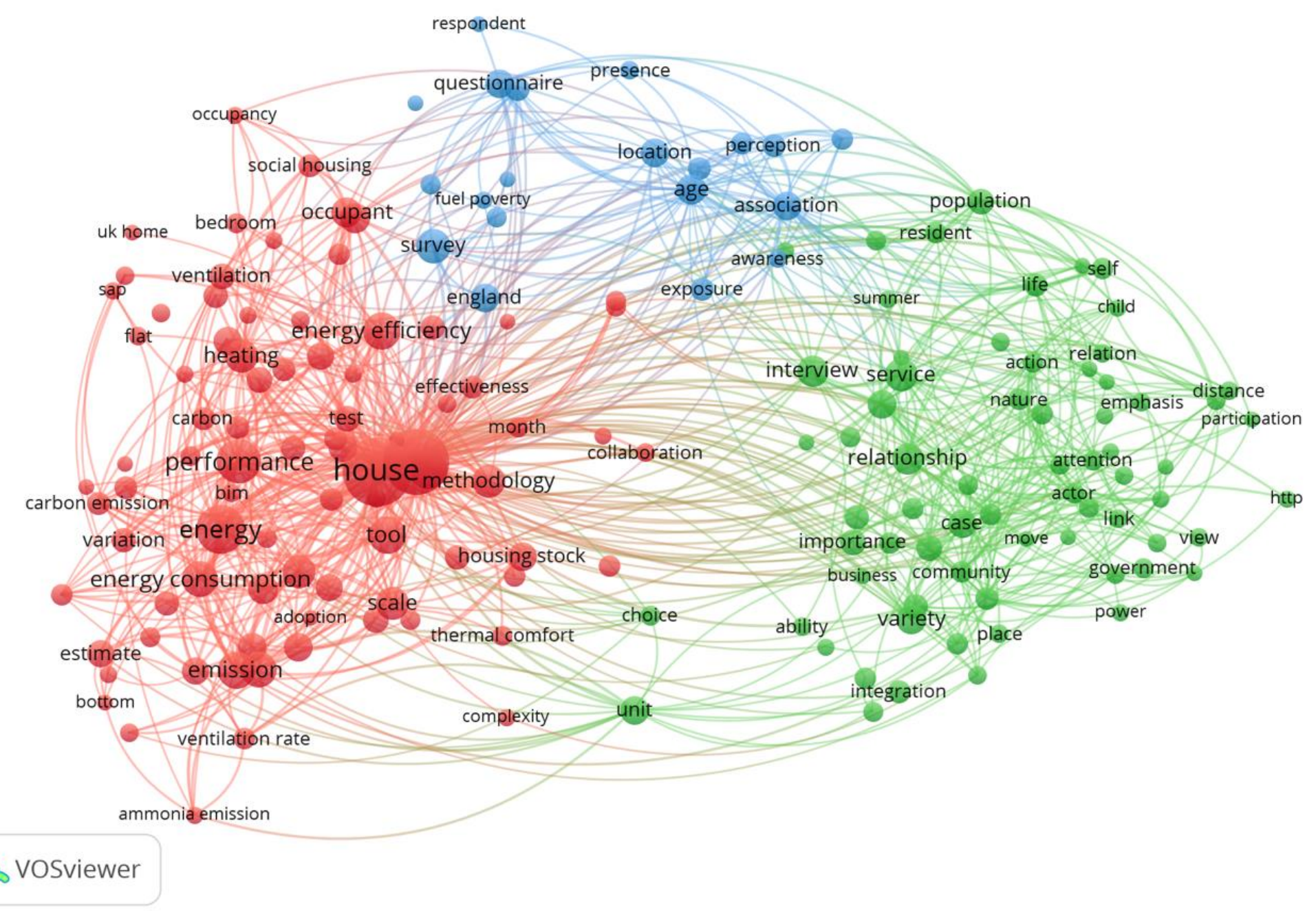


Figure 3-A Bivariate Regression Model portraying the number of houses built yearly in the UK - Time period from 1978 to 2018.

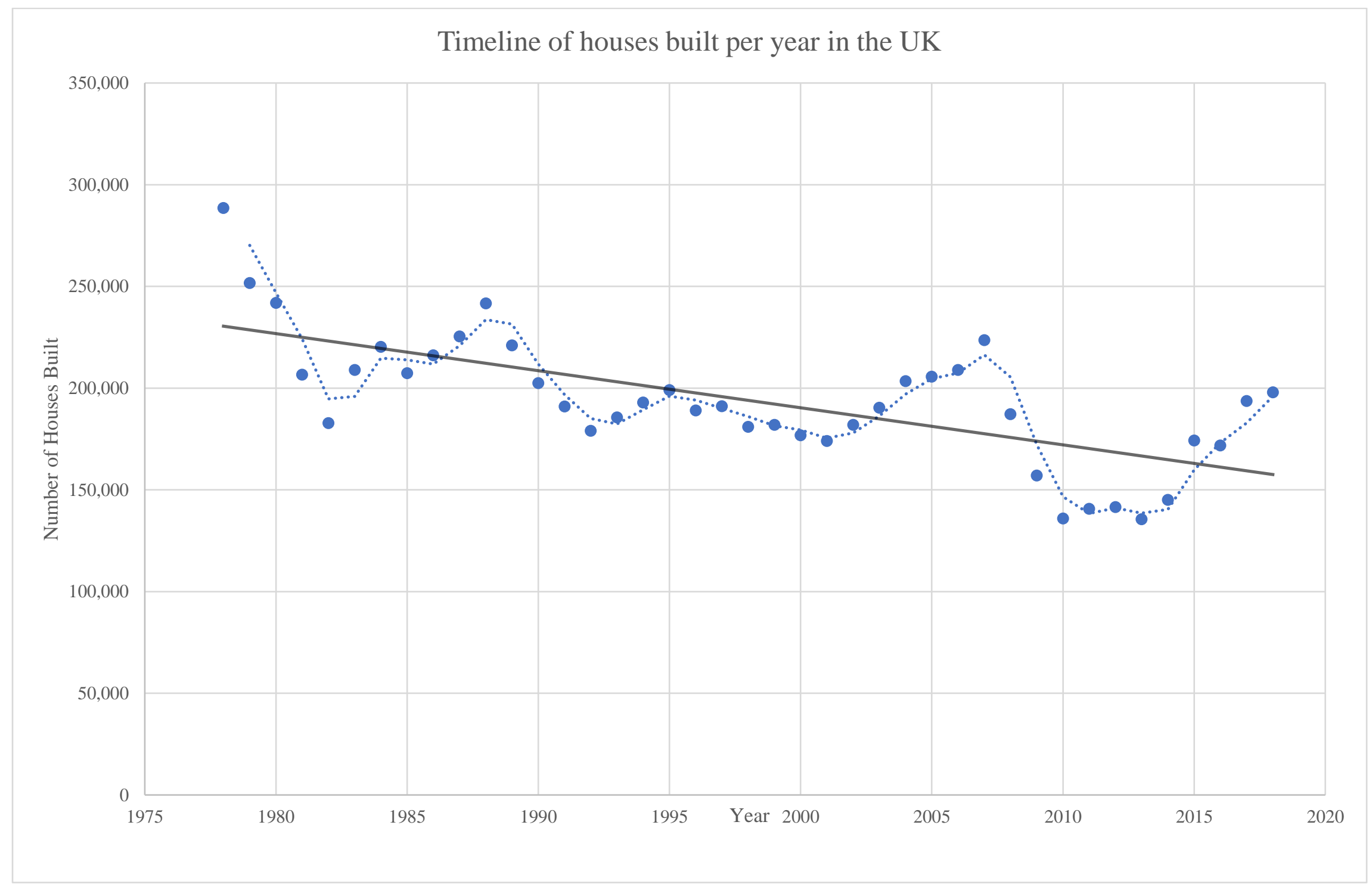


Figure 5 - Market share comparison of UK housing construction methods

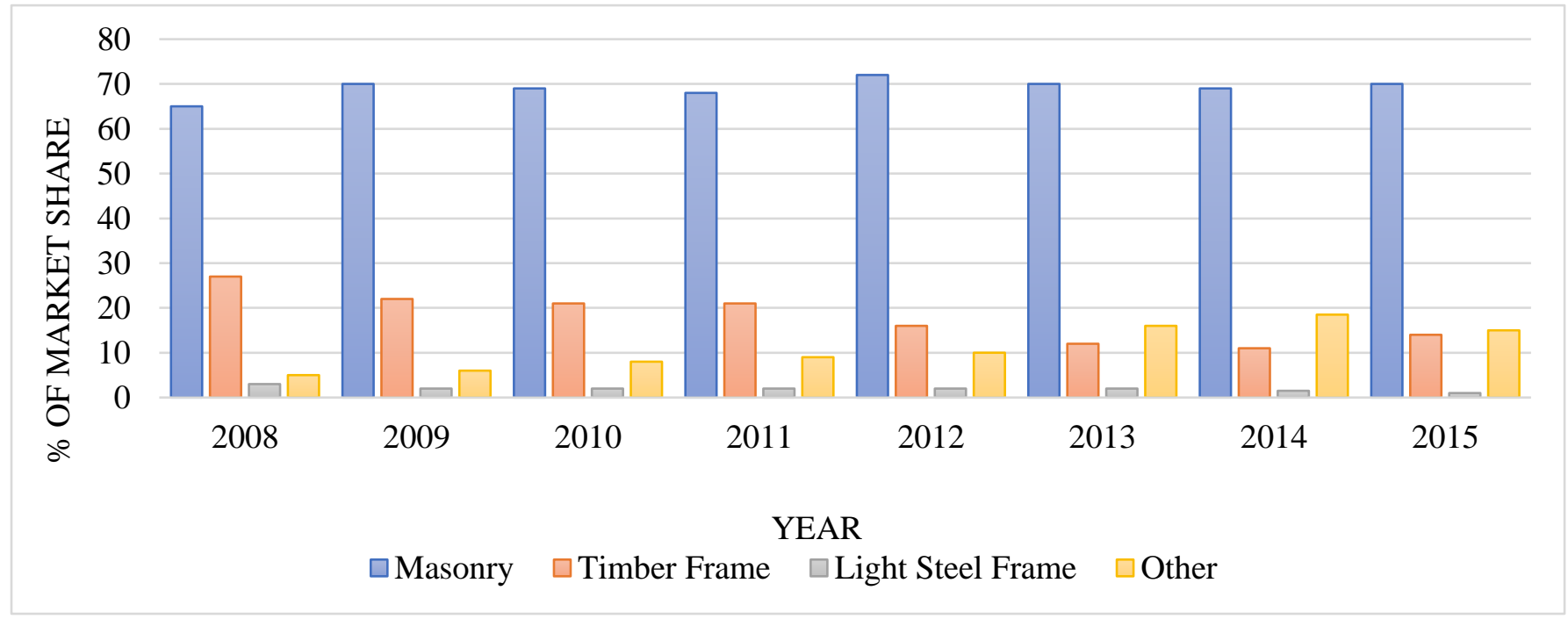

(Data obtained from: NHBC Registrations, 2016) 